\title{
STRATEGI PENGEMBANGAN BISNIS PEMOTONGAN SAPI
}

\author{
DEVELOPMENT STRATEGY OF BEEF CATTLE BUSINESS
}

\author{
Aisa Rurkinantia*)1, Rina Oktaviani**), dan Bunasor Sanim ${ }^{* * *}$ \\ *) Kampung 99 Pepohonan \\ Jl. KH. Muhasan II, Kelurahan Meruyung, Kecamatan Limo, Depok 16515 \\ **) Departemen Ilmu Ekonomi, Fakultas Ekonomi dan Manajemen, Institut Pertanian Bogor \\ Jl. Agatis Kampus IPB Darmaga, Bogor 16680 \\ ${ }^{* * *)}$ Sekolah Bisnis, Institut Pertanian Bogor \\ Jl. Raya Pajajaran, Bogor 16151
}

\begin{abstract}
The purpose of this study are 1) to identify the internal and external factors that influence development strategy of beef cattle business, 2) to make the alternative strategy, and 3) to make priority of strategy for development of beef cattle business in of PD. Kampung 99 Pepohonan. This study uses IFE and EFE Matrix, analysis SWOT matrix and QSPM. Respondens for this study are 10 persons that are 5 internal respondes, and 5 external respondes. To Determine of priority strategy, this study uses IFE and EFE matrix, SWOT matrix and QSPM analysis. The main priority strategy development strategy that can be implemented is increase cattle quality with serve the optimum feed for the cow with get enough on recovery time. The next priority strategy is to submitted decrease loan interest in working capital of the bank, multiplied of line distribution between home beef cattle and feedlot and revitalitation between home beef cattle as the place of meat proceccing to filled the market needed.
\end{abstract}

Keywords: beef cattle, PD. Kampung 99 Pepohonan, EFE,SWOT, QSPM

\begin{abstract}
Absrak: Tujuan dari penelitian ini adalah 1) untuk mengidentifikasi factor-faktor internal dan eksternal, 2) menentukan alternatif strategi, dan 3) strategi prioritas untuk mengembangkan usaha pemotongan sapi di PD. Kampung 99 Pepohonan. Penilitian ini menggunakan Matriks IFE dan EFE, Matrik SWOT dan QSPM. Jumlah responden internal sebanyak 5 orang dan eksternal sebanyak 5 orang. Hasil penelitian menunjukkan bahwa meningkatkan kualitas potongan daging sapi dengan menyediakan pakan yang optimal serta masa recovery yang cukup sebelum dilaksanakannya pemotongan sapi. Untuk strategi prioritas selanjutnya adalah dengan mengajukan penurunan bunga pinjaman modal kerja dari bank, memperbanyak saluran distribusi antar rumah potong hewan (RPH) dan Feedloot dan revitalisasi RPH sebagai tempat meat proceccing untuk memenuhi kebutuhan pasar.
\end{abstract}

Kata kunci: pemotongan sapi, PD. Kampung 99 Pepohonan, EFE ,SWOT, QSPM

\footnotetext{
${ }^{1}$ Alamat Korespondensi:

Email: aisa.rurkinantia189@gmail.com
} 


\section{PENDAHULUAN}

Laju pertumbuhan penduduk $1,49 \%$ per tahun dengan jumlah penduduk sebesar 255 ribu juta pada tahun 2015, menjadikan Indonesia merupakan pasar potensial untuk semua produk, terutama produk pertanian yang merupakan kebutuhan dasar hidup manusia. Peningkatan laju pertumbuhan ekonomi, juga akan meningkatkan daya beli masyarakat, khususnya kesadaran untuk mendapatkan pangan dengan gizi yang baik. Makanan dengan gizi yang baik menurut WHO adalah makanan dengan kadar gizi yang seimbang antara zat tenaga, zat pengatur dan zat pembangun. Salah satu bahan makanan sebagai zat pembangun bagi tubuh adalah makanan yang mengandung protein. Bahan makanan dengan nilai protein tinggi salah satunya adalah daging. Sejalan dengan pendapat Machmud (2013) yang menyatakan bahwa konsumsi pangan asal ternak yang memiliki trend terus meningkat dari tahun ke tahun adalah daging dan telur. Berdasarkan kebijakan pembangunan bidang ketahanan pangan pada Rencana Pembagunan Jangka Menengah Nasional (RPJMN) 2010-2014, satu dari lima komoditas yang dijadikan komoditas strategis berasal dari subsektor peternakan, yaitu daging sapi.

Sejalan dengan penambahan jumlah penduduk di Indonesia pula, Produk Domestik Bruto (PDB) juga mengalami peningkatan dari tahun ke tahun. Menurut Badan Pusat Statistik pada tahun 2004 laju pertumbuhan komulatif PDB Indonesia adalah $4,43 \%$ dan pada 2015 meningkat menjadi 5,10\%. Pembentukan PDB dipengaruhi oleh beberapa sektor usaha, pertanian merupakan salah satu sektor yang peranannya sangat strategis dalam pembentukan PDB, hal tersebut terlihat pada besarnya kontribusi PDB pertanian terhadap PDB nasional dengan rata-rata kontribusinya sebesar 14\% (Kementrian Pertanian, 2015). Sektor pertanian dibagi menjadi lima subsektor yaitu tanaman bahan makanan, tanaman perkebunan, peternakan dan hasilnya, kehutanan dan perikanan. Sektor peternakan berkontribusi sebesar $12 \%$ dari pembentukan PDB di sektor pertanian. Peternakan merupakan salah satu sektor yang penting untuk menunjang perekonomian masyarakat. Menurut direktorat jenderal peternakan, rata-rata konsumsi daging sapi di Indonesia pada tahun 2015 adalah 2,56 kg per kapita per tahun. Jika kita kalikan dengan jumlah penduduk Indonesia maka akan dibutuhkan 652.000 ton daging sapi untuk memenuhi kebutuhan daging di Indonesia. Jumlah ini akan terus bertambah seiring dengan kenaikan jumlah penduduk di Indonesia dan juga terus bertambah tingkat konsumsinya berdasarkan kenaikan produk domestik bruto di Indonesia.

Provinsi DKI Jakarta, Banten dan Jawa Barat merupakan pangsa pasar terbesar untuk konsumsi daging di Indonesia (BPS, 2010). Permasalahan pemenuhan kebutuhan daging sapi tidak hanya menjadi menjadi permasalahan dari ketiga Provinsi tersebutnamun juga menjadi masalah nasional. Tingginya permintaan daging sapi, dan ditunjang dengan keterbatasan suplai sapi potong, menyebabkan masih tingginya harga daging sapi, yakni Rp105.000. Presiden Jokowi tidak tinggal diam dengan masih tingginya harga daging sapi di pasar, maka beliau mempunyai program jangka pendek untuk menekan harga daging di angka Rp80.000 dengan cara mengimpor daging beku. Apabila impor daging beku terus menerus dilakukan agar terjadi penurunan harga, mengakibatkan usaha pemotongan sapi akan mengalami penurunan produksi.

Permasalahan tentang penyediaan daging sapi murah dalam negeri pun tidak sebatas ini, Indonesia sebagai negeri Agraris masih mempunyai tekad untuk swasembada sapi. Mengatasi hal ini Kementrian Pertanian dan Kementrian Perdagangan telah menyepakati izin impor sapi dengan skema, setiap $80 \%$ impor sapi bakalan, harus disertai dengan $20 \%$ sapi indukan, keputusan ini dicetuskan setelah rapat koordinasi antara Menteri Pertanian Andi Amran Sulaiman dengan Menteri Perdagangan Enggarsiasto Lukita. Para pengusaha feedloter pun merasa keberatan dengan keputusan tersebut, hal ini berkaitan dengan adanya $20 \%$ sapi indukan maka semakin tinggi beban produksi dari sapi-sapi indukan tersebut sehingga akan menghambat cash flow keuangan para feedloter tersebut. Keputusan-keputusan pemerintah seperti ini tanpa diiringi dengan solusi yang jelas, mengakibatkan gejolak harga sapi potong. Dampak lainnya dari keputusan tersebut adalah terkurasnya sapi lokal untuk dipotong, sedangkan proyeksi kebutuhan konsumsi pada tahun 2017 (Disnak, 2016) (diolah) adalah sebesar 685.000 ton atau sejumlah dengan 3,8 juta ekor sapi diantaranya dalah 700.000 ekor sapi bakalan impor dan sisanya akan tutupi dengan impor daging beku serta pemotongan sapi lokal dimana jumlah 3,8 juta tersebut sebanyak $23 \%$ dari total populasi sapi di Indonesia.

Usaha pemotongan sapi harus bersifat dinamis dalam menghadapi gejolak sebagai dampak dari kebijakan yang dikeluarkan pemerintah. Apabila impor sapi 
bakalan berkurang jumlahnya serta pertumbuhan produksi sapi potong dalam negeri tidak mencukupi kebutuhan konsumsi dan untuk memenuhui kebutuhan konsumsi dilakukan impor daging beku, maka usaha pemotongan sapi di Indonesia akan perlahan-lahan mati. Diperlukan suatu formulasi strategi yang terencana dan inovatif untuk menghadapi segala bentuk regulasi yang ada serta adanya penambahan nilai dari usaha pemotongan sapi sehingga usaha pemotongan sapi di Indonesia dapat memberikan kontribusi yang sesuai dengan kebutuhan konsumsi daging di Indonesia.

Bertempat di Desa Kalisuren, Kelurahan Tajur Halang Kabupaten Bogor, Jawa Barat, terdapat salah satu Rumah Potong Hewan (RPH) milik swasta dengan nama PD. Kampung 99 Pepohonan. PD. Kampung 99 Pepohonan, mempunyai fasilitas RPH yang sudah terstandar SNI sebagai RPH yang memenuhi standar higenitas, tata cara, layout dan berstandar animal welfare. Terbatasnya jumlah sapi impor bakalan, juga mengakibatkan berkurangnya pasokan sapi bakalan ke RPH PD. Kampung 99 Pepohonan serta adanya kenaikan harga dari pihak feedloter yang mengakibatkan menurunnya daya beli pedagang daging di RPH PD. Kampung 99 Pepohonan. Mengatasi dari ketergantungan dengan regulasi pemerintah dan pasokan sapi bakalan dari para feedolter, diperlukan formulasi strategi pengembangan untuk menjawab tantangan usaha pemotongan sapi di PD. Kampung 99 Pepohonan pada masa depan.

Penelitian terdahulu yang terkait dengan penilitian ini diantaranya adalah penelitian Nugraha (2010) dengan judul strategi pengembangan sapi potong di PT Andini Persada Sejahtera yang mempunyai tujuan untuk mengidentifikasi dan menetapkan elemenelemen dari faktor, aktor, tujuan dan alternatif strategi dari perusahaan tersebut. Teknik pengolahan dan analisis data dilakukan melalui tahapan identifikasi dan penetapan elemen hierarki, kemudian menetapkan prioritas strategi. Hasil dari penelitian tersebut menunjukkan bahwa prioritas pengembangan sapi potong di PT. Andini Persada Sejahtera adalah dengan meningkatkan strategi pemasaran dan distribusi dengan peluang yang ada, strategi ini juga mengacu pada faktor ketersediaan modal yang diberikan oleh lembaga pembiyaan (perbankan) dan ditujukan untuk mengangkap peluang pasar di industri sapi potong.

Aisyah et al. (2013) dengan penelitiannya yang berjudul strategi pengembangan usaha sapi potong (studi kasus CV Mitra Tani Farm) yang bertujuan untuk menetapkan strategi prioritas dalam pengembangan usaha sapi potong di CV Mitra Tani Farm, dan menggunakan analisis industri, analisis SWOT 4K dan QSPM ini mendapatkan hasil bahwa untuk mengembangkan usaha sapi potong di CV Mitra Tani Farm diperlukan strategi perluasan pasar. Memperluas pasar akan menunjang strategi lainnya, baik dalam hal pendanaan dan jaringan pemasaran.

Armunanto (2013) dengan penelitiannya yang berjudul strategi pengembangan ternak sapi potong melalui kemitraan di PT. Great Giant Livestock Company, juga menggunakan alat analisis IFE, EFE, analisis SWOT dan Analisis QSPM. Penelitian ini menghasilkan strategi utama untuk diimplementasikan berdasarkan hasil analisis, yaitu penambahan jumlah sapi yang dimitrakan dari enam ekor menjadi 10 ekor tiap mitra dan meningkatkan minat peternak untuk menjadi mitra. Penambahan jumlah sapi yang dimitrakan tersebut juga dapat meningkatkan minat pada pternak untuk menjadi mitra.

Dengan permasalahan yang ditemukan dan beberapa penelitian terdahulu maka penelitian ini bertujuan mengidentifikasi faktor-faktor Internal dan Eksternal yang memengaruhi pengembangan usaha sapi potong PD. Kampung 99 Pepohonan. Selanjutnya, menentukan alternatif strategi untuk pengembangan usaha pemotongan sapi di PD. Kampung 99 Pepohonan serta menentukan strategi prioritas untuk pengembangan bisnis pemotongan sapi di PD. Kampung 99 Pepohonan.

\section{METODE PENELITIAN}

Penelitian ini dilaksanakan di PD. Kampung 99 Pepohonan, yang terletak di Kalisuren Bogor sebagai kandang dan Rumah Potong Hewan utama, RPH Kadipaten, RPH Purwakarta, RPH Subang dan di Meruyung Depok sebagai kantor pusat. Sampel dalam penelitian ini adalah pihak manajerial perusahaan, pihak dinas peternakan setempat dan pihak dan data sekunder yang didapat dari perusahaan serta badanbadan statistik terkait. Penelitian akan dilaksanakan pada bulan Juli-September 2016.

Teknik pengumpulan data dalam penelitian ini menggunakan studi lapangan dan studi kepustakaan. Studi Lapangan yaitu teknik pengumpulan data dengan cara melakukan penelitian ke kandang dan RPH yang 
dikelola oleh Peternakan Kampung 99 Pepohonan serta kantor terkait secara langsung. Teknik studi lapangan antara lain wawancara, observasi, pengisian kuesioner terstruktur yang dilakukan oleh responden. Studi kepustakaan dilakukan dengan cara mempelajari dan mengkompilasi data sekunder dari bahan pustaka yang relevan.

Sumber data menggunakan data primer dan data sekunder. Data primer digunakan untuk menentukan strategi yang berpengaruh terhadap pengembangan usaha ini yang bisa dapat diperoleh dengan cara wawancara terstruktur dengan menggunakan kuesioner yang telah dibuat sebelumnya sesuai dengan masalah dan tujuan penelitian. Wawancara dilakukan terhadap responden internal yaitu jajaran top management pada instansi terkait. Selanjutnya, data primer juga diperoleh dengan melakukan pengamatan langsung (observasi) di lapangan tentang strategi pengembangan usaha pemotongan sapi yang telah dilaksanakan selama ini dan menentukan faktor-faktor internal, faktorfaktor eksternal dan prioritas alternative strategi yang mempunyai pengaruh terhadap pengembangan usaha peternakan sapi potong. Sebaliknya, data sekunder didapat dari Asosiasi pengusaha feedloter Indonesia (APFINDO), Badan Pusat Statistik (BPS), Bappeda, Dinas Kesehatan Hewan, Direktorat jendral Peternakan, studi literatur serta berbagai sumber relevan yang dapat menunjang penelitian ini.

Pengambilan contoh pada penelitian ini dilakukan dengan menggunakan penentuan responden pakar secara sengaja (purposive sampling) melalui pendekatan expertise judgement. Responden pakar dipilih dari pihak internal PD. Kampung 99 Pepohonan, sedangkan responden pakar eksternal dipilih dari pihak Dinas Peternakan Jawa Barat. Pertimbangan tersebut dilakukan dengan pertimbangan bahwa respondenresponden tersebut mempunyai kemampuan dan keahlian yang kompeten di bidang usaha pemotongan sapi. Jenis dan sumber data strategi pengembangan usaha pemotongan sapidi PD. Kampung 99 Pepohonan di Kalisuren Bogor Selengkapanya pada Tabel 1.

Teknik Pengolahan dan Analisis Data (David, 2009) menyatakan, teknik perusmusan strategi yang penting dapat diintegrasikan ke dalam kerangka keija pengambilan keputusan tiga tahap. Alat yang disajikan dalam kerangka kerja ini dapat digunakan untuk semua ukuran dan tipe organisasi dan dapat membantu penyusun strategi mengidentifikasi dan memilih strategi. Table 2 menunjukkan tahapan kerangka kerja untuk perumusan strategi komprehensif dalam menentukan strategi pengembangan usaha pemotongan sapi di PD. Kampung 99 Pepohonan.

Tahapan kerangka kerja analisis untuk perumusan strategi komprehensif yang digunakan dalam penelitian ini adalah (1) analisis IFE dan EFE yang digunakan untuk meringkas informasi dasar yang dibutuhkan untuk merumuskan strategi atau sering disebut juga sebagai tahap input; (2) SWOT (Strengths-Weakness Opportunities-Threats) sebagai tahap pencocokan yang berfokus untuk merumuskan strategi alternatifdengan mencocokkan faktor eksternal dan internal kunci;dan (3) analisis QSPM merupakan tahap keputusan yang digunakan untuk menentukan prioritas strategi.

Tabel 1. Jenis dan sumber data strategi pengembangan usaha pemotongan sapidi PD. Kampung 99 Pepohonan di Kalisuren Bogor

\begin{tabular}{lll}
\hline Jenis Data & \multicolumn{1}{c}{ Nama Data } & \multicolumn{1}{c}{ Stunber } \\
\hline Primer & Penentuan faktor internal dan ekstemal & Direktur utama PD. Kampung 99 Pepohonan, \\
& $\begin{array}{l}\text { Penentuan bobot faktor strategis internal dan ekstemal } \\
\text { Denentuan peringkat faktor strategis internal dan keuangan PD. Kampung 99 Pepohonan, } \\
\text { ekstemal }\end{array}$ & $\begin{array}{l}\text { Manajer RPH PD. Kampung 99 Pepohonan } \\
\text { Kalisuren-Bogor, Manajer RPH Purwakarta, }\end{array}$ \\
& Manajer RPH Kabupaten Majalengka \\
\hline Penilaian SWOT & Direktur utama PD. Kampung 99 Pepohonan, \\
& Denentuan prioritas strategi & Manajer RPH PD. Kampung 99 Kalisuren-Bogor, \\
& Manajer RPH Purwakarta, Manajer RPH Kabupaten
\end{tabular}

Sekunder Populasi penduduk, Populasi ternak, Produksi temak, Badan Pusat Statistik, Direktorat Jenderal Konsumsi ternak, Pemotongan ternak, dan lain-lain Peternakan, Dinas Peternakan Provinsi Jawa Barat, Dinas Peternakan Kabupaten Bogor, Dinas Peternakan Kabupaten Punvakarta, Dinas Peternakan Kabupaten Majalengka 
HASIL

\section{Analisis Faktor Internal}

Analisis Faktor Internal dilakukan terhadap lingkungan internal perusahaan PD. Kampung 99 Pepohonan dalam rangka untuk mengetahui strategi pengembangan usaha pemotongan sapi di PD. Kampung 99 Pepohonan. Dalam melakukan analisis tersebut ditentukan faktor-faktor strategis yang merupakan kekuatan dan kelemahan di dalam lingkungan internal perusahaan. Hasil dari diskusi dengan jajaran top management pada lini bisnis di pemotongan sapi di PD. Kampung 99 Pepohonan, didapatkan faktor-faktor yang merupakan kekuatan dan kelemahan dalam mengembangkan strategi usaha pemotongan sapi di PD. Kampung 99 Pepohonan yang selengkapnya dijabarkan pada Tabel 3.

\section{Analisis Faktor Eksternal}

Analisis faktor eksternal dilakukan terhadap lingkungan eksternal perusahaan PD. Kampung 99 Pepohonan dalam rangka untuk mengetahui strategi pengembangan usaha pemotongan sapi di PD. Kampung 99 Pepohonan, untuk melakukan analisis tersebut ditentukan faktorfaktor strategis yang merupakan peluang dan ancamandi luar lingkungan perusahaan. Hasil dari diskusi dengan jajaran top management pada lini bisnis di pemotongan sapi di PD. Kampung 99 Pepohonan, didapatkan faktor-faktor yang merupakan peluang dan ancaman dalam mengembankan strategi usaha pemotongan sapi di PD. Kampung 99 Pepohonan yang selengkapnya dijabarkan pada Tabel 4.

Tabel 2. Tahapan kerangka kerja

\begin{tabular}{|c|c|}
\hline \multicolumn{2}{|c|}{ TAHAP 1 : TAHAP INPUT } \\
\hline $\begin{array}{c}\text { Matriks Evaulasi Faktor Eksternal } \\
\text { (External Factor Evaluation-EFE) }\end{array}$ & $\begin{array}{c}\text { Matriks Evaulasi Faktor Internal } \\
\text { (Internal Factor Evaluation-IFE) }\end{array}$ \\
\hline \multicolumn{2}{|c|}{ TAHAP 2 : TAHAP PENCOCOKAN } \\
\hline \multicolumn{2}{|c|}{ TAHAP 3: TAHAP KEPUTUSAN } \\
\hline Matriks Ancaman-Peluang-Kelemahan-Kekuatan (Strength- Weakness-Opportunities- Threaths/SWOT) \\
\hline \multicolumn{2}{|c|}{ TAtriks Perencanaan Strategis Kuantitatif (Quantitative Stratetic Planning Matrix/QSPM) } \\
\hline
\end{tabular}

Tabel 3. Matriks evaluasi faktor internal strategi pengembangan usaha pemotongan sapi di PD. Kampung 99 Pepohonan

\begin{tabular}{lccc}
\hline \multicolumn{1}{c}{ Faktor-faktor internal } & Bobot & Peringkat & Skor bobot \\
\hline Kekuatan & & & \\
Rumah potong hewan yang terstandar animal welfare oleh MLA & 0,08 & 4 & 0,34 \\
Tenaga potong ahli yang sudah tersertifikasi halal & 0,12 & 3 & 0,35 \\
Ketersediaan pakan yang optimal & 0,10 & 4 & 0,39 \\
Kontrol dan pengawasan kesehatan sapi sebelum di potong & 0,10 & 3 & 0,30 \\
Jaringan pemasaran yang luas & 0,12 & 3 & 0,36 \\
Kelemahan & & & \\
Ketidakterersediaan cold storage & 0,11 & 2 & 0,22 \\
Masa recovery yang belum cukup untuk sapi yang akan dipotong & 0,11 & 1 & 0,11 \\
Sulitnya pengadaan sapi bakalan potong & 0,11 & 2 & 0,23 \\
Pembayaran yang kurang lancar dari pedagang & 0,07 & 2 & 0,15 \\
Ketidakterersediaan modal kerja yang memadai & 0,08 & 1 & 0,08 \\
$\quad$ Total & 1,00 & & 2,51 \\
\hline
\end{tabular}


Tabel 4. Matriks evaluasi faktor eksternal strategi pengembangan usaha pemotongan sapi di PD. Kampung 99 Pepohonan

\begin{tabular}{lccc}
\hline \multicolumn{1}{c}{ Faktor-faktor eksternal } & Bobot & Peringkat & Skor bobot \\
\hline Peluang & & & \\
Regulasi harga sapi yang stabil & 0,09 & 4 & 0,38 \\
Dukungan masyarakat sekitar & 0,13 & 3 & 0,38 \\
Permintaan pasar daging yang semakin terspesifikasi & 0,08 & 4 & 0,32 \\
Adanya pelatihan dari pemerintah untuk sertifikasi halal tukang potong & 0,10 & 3 & 0,30 \\
Revitalisasi RPH oleh pemerintah sebagai tempat proceccing daging & 0,10 & 4 & 0,38 \\
Ancaman & & & \\
Keterbatasan saluran distribusi antar RPH dan Feedlot & 0,10 & 2 & 0,20 \\
Ketidakstabilan ketersediaan sapi bakalan baik Impor maupun lokal & 0,11 & 4 & 0,44 \\
Banyaknya dagingimpor yang masuk ke Indonesia & 0,12 & 2 & 0,25 \\
Regulasi pemerintah yang belum konsisten dalam mengatur suplai sapi potong & 0,10 & 3 & 0,30 \\
Pinjaman dana bank dengan bunga tinggi & 0,07 & 3 & 0,21 \\
\multicolumn{1}{c}{ Total } & 1,00 & & 3,15 \\
\hline
\end{tabular}

\section{Strategi Alternatif Pengembagan Usaha Pemotongan Sapi}

Analisis matriks SWOT bertujuan menentukan strategi alternatif pengembangan usaha pemotongan sapi di PD. Kampung 99 Pepohonan, dimana faktorfaktornya menggunakan hasil dari analisis IFE dan EFE. Selanjutnya, Matriks SWOT bermanfaat untuk mendalami faktor-faktor strategis yang sigap dengan perkembangan usaha pemotongan sapi di lapangan, serta dapatmenggambarkan secara jelas peluang yang harus diraih, ancaman yang harus dihindari, serta besarnya kekuatan dan adanya kelemahan yang harus disesuaikan guna mendapatkan formulasi strategi pengembangan usaha pemotongan sapi di PD. Kampung 99 Pepohonan. Penyesuaian antara kekuatan, kelemahan dan peluang serta ancaman adalah untuk menghasilkan strategi alternatif yang layak, bukan untuk memilih strategi mana yang terbaik. Tidak semua strataegi yang dikembangan dalam matriks SWOT akan dipilih untuk implementasi. Strategi alternatif pengembangan usaha pemotongan sapi di PD. Kampung 99 Pepohonan dapat dilihat pada Gambar 1.

\section{Strategi Prioritas Pengembangan Usaha Pemotongan Sapi}

Analisis QSPM digunakan untuk menentukan strategi relatifyang menarik dari strategi-strategi yang bervariasi dari hasil analisis SWOT sehingga dapat dipilih strategi mana yang dianggap baik untuk diimplementasikan dalam mengembangkan strategi usaha pemotongan sapi di PD. Kampung 99 Pepohonan. Teknik ini juga merupakan salah satu teknik analisis yang didesain untuk menentukan daya tarik relatif dari alternatif tindakan yang layak. Strategi alternatif hasil dari analisis SWOT yang menjadi set strategi dalam analisis QSPM pada penelitian strategi pengembangan usaha pemotongan sapi di PD. Kampung 99 Pepohonan, yaitu 1) meningkatkan kualitas potongan daging sapi dengan menyediakan pakan yang optimal; 2) pelatihan tenaga potong ahli dari pemerintah untk sertifikasi halal; 3) revitalisasi RPH sebagai meat processing untuk memenuhi permintaan pasar; 4) penetapan harga yang stabil sebagai daya tawar ke pedagang agar pembayaran lancar; 5) masa recovery yang cukup untuk sapi yang akan dipotong; 6) memperbanyak dan memperbaiki saluran distribusi antar RPH dan feedlot; 7) meningkatkan kontrol kesehatan sapi potong; 8) mengajukan penurunan bunga pinjaman modal kerja dari bank.

Hasil dari strategi tersebut selanjutnya ditentukan daya tarik relatifnya dengan menyebarkan kuesioner QSPM. Jumlah responden untuk menentukan daya tarik relatifnya adalah lima orang. Hasil yang didapatkan disajikan pada Tabel 5. Dengan diperoleh alternatifalternatif strategi prioritas guna melaksanakan strategi pengembangan usaha pemotongan sapi di PD. Kampung 99 Pepohonan. Meningkatkan kualitas potongan daging sapi dengan menyediakan pakan yang optimal merupakan faktor suksesi dengan prioritas 1 dengan skor tertinggi, yakni 6,275. 


\begin{tabular}{|c|c|c|}
\hline Faktor Internal & $\begin{array}{l}\text { Strength }(\mathrm{S}) \\
\text { 1. RPH yang sesuai dengan animal welfare }(0,34) \\
\text { 2. Tenaga potong ahli yang sudah tersertifikasi } \\
\text { halal }(0,35) \\
\text { 3. Ketersediaan pakan yang optimal }(0,39) \\
\text { 4. Kontrol dan pengawasan kesehatan sapi } \\
\text { sebelum di potong }(0,30) \\
\text { 5. Kontrol kebersihan RPH }(0,36)\end{array}$ & $\begin{array}{l}\qquad \text { Weaknesses }(\mathrm{W}) \\
\text { 1. Ketersediaan cold storage }(0,22) \\
\text { 2. Masa recovery yang cukup untuk sapi yang } \\
\text { akan dipotong }(0,11) \\
\text { 3. Kontrol kualitas mutu daging }(0,23) \\
\text { 4. Pembayaran yang lancar dari pedagang }(0,15) \\
\text { 5. Ketersediaan modal kerja yang memadai }(0,08)\end{array}$ \\
\hline $\begin{array}{l}\text { Opportunities }(\mathrm{O}) \\
\text { 1. Regulasi harga sapi yang stabil }(0,38) \\
\text { 2. Dukungan masyarakat sekitar }(0,38) \\
\text { 3. Permintaan pasar daging yang semakin } \\
\text { terspesifikasi }(0,32) \\
\text { 4. Adanya pelatihan dari pemerintah untuk } \\
\text { sertifikasi halal tukang potong }(0,30) \\
\text { 5. Revitalisasi RPH oleh pemerintah sebagai } \\
\text { tempat proceccing daging }(0,38)\end{array}$ & $\begin{array}{l}\text { Strategi S-O } \\
\text { 1. Ketersediaan pakan yang optimal untuk } \\
\text { meningkatkan kualitas potongan daging sapi } \\
(\mathrm{S} 3, \mathrm{O} 3) \\
\text { 2. Pelatihan tenaga potong ahli untuk sertitikasi } \\
\text { halal }(\mathrm{S} 2, \mathrm{O} 4)\end{array}$ & $\begin{array}{l}\text { Strategi W-O } \\
\text { 3. Revitalisasi RPH sebagai meat proceccing } \\
\text { dengan mengadakan cold storage untuk } \\
\text { memenuuhi permintaan pasar yang } \\
\text { terspesifikasi (W1,O1,O2,O5) } \\
\text { 4. Regulasi harga yang stabil sebagai daya tawar } \\
\text { ke pedagang agar pembayaran lancar }(\mathrm{O} 1, \mathrm{~W} 4) \\
\text { 5. Memenuhi permintaan pasar dan menghasikan } \\
\text { kualitas daging yang bagus dengan masa } \\
\text { recovery yang cukup (O3,W2,W5) }\end{array}$ \\
\hline $\begin{array}{l}\text { Threats }(\mathrm{T}) \\
\text { 1. Keterbatasan saluran distribusi antar RPH } \\
\text { dan Feedloot }(0,20) \\
\text { 2. Ketidakstabilan ketersediaan sapi bakalan } \\
\text { impor maupun lokal }(0,22) \\
\text { 3. Banyaknya daging impor yang masuk ke } \\
\text { Indonesia }(0,12) \\
\text { 4. Regulasi pemerintah yang belum } \\
\text { konsisten }(0,20) \\
\text { 5. Pinjaman dana bank dengan bunga tinggi } \\
(0,14)\end{array}$ & $\begin{array}{l}\text { Strategi S-T } \\
\text { 6. Memperbanyak dan memperbaiki saluran } \\
\text { distribusi antar RPH dan Feedloot (T1,S4,S1) } \\
\text { 7. Meningkatkan control kesehatan sapi potong } \\
\text { (T2,T4,S4,S5) }\end{array}$ & $\begin{array}{l}\text { Strategi W-T } \\
\text { 8. Mengajukan penurunan bunga modal kerja dari } \\
\text { bank (T5,W5) }\end{array}$ \\
\hline
\end{tabular}

Gambar 1. Matriks SWOT strategi alternatif pengembangan usaha pemotongan sapi di PD. Kampung 99 Pepohonan

Tabel 7. Hasil QSPM penentuan strategi prioritas pengembangan usahapemotongan sapi

\begin{tabular}{lcc}
\hline \multicolumn{1}{c}{ Alternatif strategi } & Total TAS & Peringkat \\
\hline Ketersediaan pakan yang optimal untuk meningkatkan kualitas potongan daging sapi & 6,275 & 1 \\
Pelatihan tenaga potong ahli untuk sertifikasi halal & 4,818 & 8 \\
Revitalisasi RPH sebagai tempat meat processing dengan mengadakan cold storage & 5,968 & 5 \\
untuk memenuhi permintaan pasar yang terspesifikasi & & \\
Penetapan harga yang stabil sebagai daya tawar ke pedagang agar pembayaran lancar & 5,816 & 6 \\
Masa recovery yang cukup untuk sapi yang akan dipotong & 6,075 & 4 \\
Memperbanyak dan memperbaiki saluran distribusi antar RPH dan feedloot & 6,095 & 3 \\
Meningkatkan kontrol kesehatan sapi & 5,406 & 7 \\
Mengajukan penurunan bunga modal kerja dari bank & 6,169 & 2 \\
\hline
\end{tabular}

\section{Implikasi Manjerial}

Dalam proses pengembangan usaha pemotongan sapi di PD. Kampung 99 Pepohonan perlu meningkatkan strategi penyediaan pakan yang optimal untuk meningkatkan kualitas potongan daging, selain itu diperlukan masa recovery yang cukup untuk sapi yang akan dipotong. Strategi ini perlu didukung oleh permodalan yang kuat dari pihak perbankan dan didukung dengan penurunan tingkat bunga pinjaman. Strategi perluasan saluran distribusi dan pemasaran ikut turut serta dalam pengembangan usaha pemotongan sapi di PD. Kampung 99 Pepohonan.

\section{KESIMPULAN DAN SARAN}

\section{Kesimpulan}

Hasil dan pembahasan dari penelitian yang dilakukan, dapat ditarik simpulan faktor-faktor internal dari analisis IFE yang merupakan kekuatan pada usaha pemotongan sapi di PD. Kampung 99 Pepohonan adalah rumah potong hewan yang terstandar animal welfare, tenaga potong ahli yang sudah tersertifikasi halal, ketersediaan pakan yang optimal, kontrol dan pengawasan kesehatan sapi sebelum dipotong, jaringan pemasaran yang luas. 
Faktor-faktor internal yang berupa ancaman adalah ketidaksediaan cold storage, masa recovery yang belum cukup untuk sapi yang dipotong, sulitnya pengadaan sapi potong, pembayaran yang tidak lancar dari pedagang, ketidaksediaan modal kerja yang memadai. Faktor-faktor eksternal dari analisis EFE yang merupakan peluang adalah regulasi harga yang stabil, dukungan masyarakat sekitar, permintaan pasar daging yang semakin terspesifikasi, adanya pelatihan dari pemerintah untuk sertifikasi halal tukang potong, revitalisasi RPH oleh pemerintah sebagai tempat meat processing. Selanjutnya, faktor-faktor eksternal perusahaan yang berupa ancaman adalah keterbatasan saluran distribusi antar RPH dan feedlot, ketidakstabilan ketersediaan sapi potong baik impor maupun lokal, banyaknya daging impor yang masuk ke Indonesia, kebijakan pemerintah yang belum konsisten dalam mengatur suplai sapi potong, pinjaman modal kerja dengan bunga yang tinggi.

Alternatif strategi yang didapat dari analisis SWOT matriks untuk pengembangan usaha pemotongan sapi di PD. Kampung 99 Pepohonan adalah ketersediaan pakan yang optimal untuk meningkatkan kualitas potongan daging sapi, pelatihan tenaga potong ahli untuk sertifikasi halal, revitalisasi RPH sebagai tempat meat processing dengan mengadakan cold storage untuk memenuhi permintaan pasar yang terspesifikasi, regulasi harga yang stabil sebagai daya tawar ke pedagang agar pembayaran lancar, memenuhi permintaan pasar untuk menghasilkan kualitas daging yang bagus dengan masa recovery yang cukup pada sapi yang akan dipotong, memperbanyak saluran distribusi antar RPH dan feedlot dan memperluas jaringan pemasaran, meningkatkan kontrol kesehatan sapi yang akan dipotong, mengajukan penurunan bunga modal kerja dari bank. Selanjutnya, strategi prioritas untuk pengembangan usaha pemotongan sapi di PD. Kampung 99 Pepohonan dengan analisis QSPM, didapatkan hasil strategi tertinggi dengan skor 6,27 adalah strategi menyediaakan pakan yang optimal untuk meningkatkan kualitas potongan daging.

\section{Saran}

Saran yang diusulkan untuk penelitian lebih lanjut adalah menentukan jumlah pakan yang diperlukan untuk menghasilkan kualitas potongan daging yang optimal sesuai dengan masing-masing jenis sapi baik sapi impor maupun lokal. Di samping itu, perlunya menentukan model hilirisasi usaha pemotongan sapi. Hal ini penting untuk menjadikan daging hasil potongan dari rumah potong hewan dalam negeri dapat mempunyai nilai jual yang tinggi dengan memperbanyak produk-produk olahan daging.

\section{DAFTAR PUSTAKA}

Aisyah SA, Sanim B, Maulana A. 2013. Strategi pengembangan usaha sapi potong: studi kasus CV Mitra Tani Farm. Jurnal Manajemen dan Agribisnis 10(2): 109-116.

Armunanto D. 2013. Strategi Pengembangan Ternak Sapi Potong Melalui Kemitraan di PT GGLC [jurnal]. Sekolah Pascasarjana. Bogor: Institut Pertanian Bogor.

[BPS] Badan Pusat Statistik. 2010.Proyeksi penduduk menurut provinsi, 2010-2035 (ribuan). https://www.bps.go.id/linkTabelStatis/ view/id/1274 [20 Juli 2016].

David FR. 2009. Strategic Management Concept and Cases. New Jersey: Francis Marion University Florence 13th Pearson.

DISNAK]Dinas PeternakanJawaB a $\mathrm{r}$ a t. .20016 . Statistik Peternakan 2014. http://disnak. jabarprov. go.id/ index.php/ subblog/component/ fbcGFnZXM\%201 1MzAw/9 [Okt 2016].

Nugroho S. 2010. Strategi pengembangan usaha peternakan sapi potong di PT Andini Persada Sejahtera [tesis]. Bogor: Institut Pertanian Bogor.

Machmud A. 2013. Analisis daya saing dan strategi pengembangan peternakan sapi potong di provinsi Sulawesi Selatan [disertasi]. Bogor: Institut Pertanian Bogor. 